\title{
Dealing with the Past: Definitions AND DESCRIPTIONS OF THE History OF TRANSLATION
}

ABORDANDO EL PASADO: DEFINICIONES Y DESCRIPCIONES DE LA HISTORIA DE LA TRADUCCIÓN

S'OCCUPER DU PASSÉ : DÉFINITIONS ET DESCRIPTIONS DE L'HISTOIRE DE LA TRADUCTION

\section{Pilar Ordóñez-López}

Ph. D. in Translation, Universidad de

Granada, Spain.

Senior Lecturer, Department of

Translation and Communication,

Universitat Jaume I, Spain.

mordonez@uji.es

https://orcid.

org/0000-0002-5881-9364

\begin{abstract}
This study examines how the history of translation has been presented to a wide readership in reference works such as translation studies encyclopedias and handbooks, providing valuable insights into the evolution of the perspectives from which the definition and description of this area has been approached over time. Our study of reference works published over a period of fifteen years shows that attempts have been made to construct an epistemic and methodological framework (a prerequisite for systematic historical enquiry), to define the object(s) of study, and to provide a comprehensive account of the concept of translation throughout history. However, the multifaceted nature of the history of translation makes it difficult to provide clear-cut definitions and descriptions, which makes this a rather diffuse area of knowledge. Furthermore, despite recurrent calls for a more inclusive approach, the account of the past of translation continues to be predominantly canonical and Westernized.
\end{abstract}

Keywords: translation theory; history of translation; translation studies; reference works on translation.

\section{RESUMEN}

El presente trabajo consiste en una revisión crítica de cómo se ha presentado la historia de la traducción a un público más amplio a través de obras de referencia sobre la traducción, como enciclopedias y manuales, con el fin de evaluar la evolución en las perspectivas desde las que se ha abordado la definición y descripción de esta área de conocimiento. Nuestro estudio de obras de referencia publicadas durante un periodo de quince años revela que se ha tratado de construir un marco epistémico y metodológico (lo que constituye un prerrequisito para la investigación histórica), de definir el objeto (o los objetos) de estudio, y de proponer una revisión "universal" del concepto de la traducción a través de la historia. No obstante, la naturaleza multifacética de la historia de la traducción hace difícil proporcionar definiciones nítidas y descripciones acotadas, lo cual la convierte en un área de conocimiento relativamente difusa. Por otro lado, pese a los repetidos llamamientos para adoptar una perspectiva más inclusiva, el relato histórico de la traducción sigue siendo eminentemente canónico y occidental.

Palabras clave: teoría de la traducción; historia de la traducción; estudios de traducción; obras de referencia sobre la traducción.

Received: 2019-06-07 / Accepted: 2020-03-02 / Published: 2020-09-17

https:/doi.org/10.17533/udea.ikala.v25n03a11 


\section{RÉSUMÉ}

Ce travail présent un examen critique sur la manière dont l'histoire de la traduction a été présentée à un public plus large par le biais d'ouvrages de référence sur la traduction tels que des encyclopédies et des manuels, afin d'évaluer l'évolution des perspectives à partir de lesquelles la définition et la description de ce domaine de connaissance ont été abordées. Notre étude d'ouvrages de référence publiés sur une période de quinze ans révèle que l'on s'est efforcé de construire un cadre épistémique et méthodologique (ce qui est une condition préalable à la recherche historique), de définir l'objet (ou les objets) d'étude, et de proposer une révision "universelle" du concept de la traduction au cours l'histoire. Toutefois, la nature polyédrique de l'histoire de la traduction rend difficile de fournir de définitions claires et de descriptions restreintes, ce qui en fait un domaine de connaissance relativement flou. Par ailleurs, malgré les appels répétés pour une approche plus inclusive, le récit historique de la traduction reste profondément canonique et occidental.

Mots clés : théorie de la traduction; histoire de la traduction ; traductologie ; ouvrages de référence sur la traduction. 


\section{Introduction}

Although the history of translation has been the focus of innumerable studies, the wide variety of co-existing approaches, objects of study, scopes and methods makes defining it difficult, whether as an entity, an area of knowledge or research, a branch of translation studies, or simply as the narrated discourse of the past of translation. This difficulty stems from the fact that historical research can involve both process- and functionoriented activities as well as translation theories, criticism and training, as observed by D'hulst (2010, pp. 398-399) in reference to Holmes's map of the discipline. Furthermore, inherent to any historical study, the spatial and temporal dimensions add complexity when attempting to provide universal, standardized definitions and descriptions for the history of translation. In addition, from an epistemic perspective, the interdisciplinary nature of this area, situated between the long-established discipline of history and a relatively new one, translation studies (which itself is also characterized by its interdisciplinarity), calls for a cautious and integrative approach to successfully combine insights from both disciplines.

Some scholars have drawn attention to the need to build the history of translation (e.g. Radó, 1964; Bassnett, 1980; Berman, 1984), sometimes regarded as the "poor relation" (Lépinette, 1997, p. 2) of the family of Translation Studies. In recent decades, attempts have been made, on the one hand, to systematize and somehow standardize the history of translation and, on the other hand, to develop the necessary scaffolding for translation history to develop as an area of research within translation studies. Notable contributions on methodology have been made, e.g. Pym, 1998, and special issues of some of the most renowned journals on translation have been dedicated to the history of translation, e.g. Meta, 49(3), 2004 and 50(3), 2005; The Translator, 20(1), 2014.

This work presents a critical review of the entries and chapters on the history of translation included in reference works on translation with the aim of examining how this area is covered and introduced to a (potentially) wide readership of both specialists and non-specialists. Reference works are useful tools for evaluating the state of the art and the evolution of an area of knowledge as they usually provide a brief account of the most significant developments and contributions. At the same time, reference works are a kind of map of a discipline; they can be considered to be de facto ontologies of the field of knowledge. Furthermore, due to the defining characteristics and function of reference works, this examination of entries on the history of translation in encyclopedias, handbooks, guides, etc., will allow us to identify some commonalities and trends as well as strong and weak points, in the presentation and definition of the area. Special issues on the history of translation are not included in this paper due to their more in-depth approach to the object of study and the fact that they are usually not intended to provide readers with a general overview of the area but instead tend to focus on specific areas or the latest trends within translation history. This investigation covers a period of fifteen years and will shed light on the way the history of translation has been and is being conceived, which ultimately has a direct effect on how scholars deal with the past of translation.

\section{"History of Translation" in Reference Works}

According to the Lexico.com (Oxford University Press, 2020), a reference work is "a source of factual information (originally a printed work, but now also an electronic resource) intended for research or consultation on individual matters rather than continuous reading." They can take the form of dictionaries, indexes, bibliographies, encyclopedias, handbooks, etc.; thanks to their structure, they are useful resources for obtaining specific information at a glance. Due to their nature, reference works are often used as learning tools and they are, to some extent, comprehensive introductions to the mapping of a discipline, thus 
playing an important role in establishing the ontological foundations of this area of knowledge. The way they are structured and the concepts, topics and data in general that they include, contribute to the construction of the epistemic framework of the discipline and to the dissemination of definitions, descriptions, discourses, etc.

In order to evaluate how the history of translation as an area of study has been described and presented to knowledge community members and outsiders in reference works, entries and chapters dedicated to the history of translation are examined below. To obtain a list of reference works, the Translation Studies Bibliography database was used. Title searches (using the keywords "encyclopedia"/ "encyclopaedia", "dictionary”, "handbook", "manual", "guide" and "companion") were conducted, and works focusing on a specific type of translation such as literary translation, machine translation, etc. as well as practice-oriented works, usually with a focus on teaching (especially in the case of manuals and handbooks), were discarded (see Appendix).

"History of Translation" made a grand entrance in the Routledge Encyclopedia of Translation Studies (Baker \& Malmkjær, 1998). This is the first encyclopedia on translation studies and can be considered to be one of the first influential, comprehensive reference works on translation studies. Since then, the history of translation has been included in most reference works published within the discipline and presented from different perspectives. The entries and chapters devoted to the history of translation are usually written by internationally renowned scholars based in a wide variety of countries, not just in Europe, which, theoretically, should be a good starting point to prevent the adoption of a hegemonic Eurocentric perspective. Nevertheless, as shown in the following sections, a Eurocentric perspective (or at least a clear focus on the Western tradition), can be observed in most cases. The reference works examined cover a time period of fifteen years (1998-2013), allowing us to evaluate how the conception of the history of translation has evolved. The investigation carried out here is limited to the history of translation, though it is noteworthy that, with the exception of the Handbuch Translation (Snell-Hornby, et al., 1999), none of the works examined make a clear distinction between the history of translation and the history of interpreting. In fact, as pointed out by Takeda \& Baigorri (2016), "historical research has traditionally occupied a subordinate position in interpreting studies, which itself is considered a subdiscipline of translation studies" (2016, p. viii); nevertheless, the history of interpreting has recently become the object of an increasing number of studies. This has also led to its increasing presence in reference works; for instance, the first section of The Routledge Handbook of Interpreting (2015) is devoted to the history of interpreting.

The examination of the entries and chapters covering the history of translation ${ }^{1}$ reveals that there are two different approaches to this object of study: i) entries in which the history of translation is approached from an epistemic perspective, aimed at providing definitions, determining the scope and functions, discussing methodological issues, etc.; and, ii) entries in which a brief summary of the history of translation, usually a canonical account, is provided. In both cases these entries and chapters contribute to the dissemination of information about the history of the discipline, either on the historical events, texts, periods or authors, or on the definition and epistemic configuration of the history of translation itself, thus making a (potentially) significant contribution to the introduction, definition and development of this area of research.

1 Neither the Dictionnaire universel des traducteurs (Hoof, 1993) nor the Diccionario histórico de la traducción en España (Lafarga \& Pegenaute, 2009) deal directly with the history of translation as an area of knowledge. Hoof (1993) focuses on the "aspect biographique des acteurs mêmes de la traduction" (Hoof, 1993: vii) while Lafarga and Pegenaute (2009) deal with the analysis of translation and translators throughout history both in the target (literary) and source cultures, and also includes a section on non-literary translation and interpreting. 


\section{Epistemology-Oriented Entries}

Entries and chapters which adopt an epistemology-oriented approach share a common structure and an interest in providing this area of study with a solid and clearly delimited basis. The inherent interdisciplinarity of the "history of translation" as well as the multifaceted, humanistic and culture-bound nature of translation make it difficult to establish clear-cut definitions and limits (something which becomes even more complicated when a historical perspective is incorporated) as the concept of translation has evolved over time. Despite the efforts to provide the reader with an informative and well-structured overview of the area of study, most entries point out both the highly fragmented state of affairs and the existence of considerable overlap between different approaches.

\section{History of Translation (Woodsworth, 1998)}

In the first edition of the Routledge Encyclopedia of Translation Studies (Baker \& Malmkjær, 1998), the history of translation is not only dealt with in the corresponding entry; "Part II: History and Traditions" (1998, pp. 295-582) is dedicated to the different translation traditions (e.g. British tradition, Arabic tradition) and consists of overviews of the most representative features, periods, translation schools and translators of each cultural tradition ${ }^{2}$. These two parts are an illustrative example of the two general approaches mentioned above. In "Part I: General" (1998, pp. 3-294), the history of translation is presented from an epistemic, ontological perspective, whereas the second part, in principle, could be included in the "Descriptive Historical Entries" section in this paper; but the in-depth approach it adopts means that it is not comparable to the brief and general accounts that typify the entries and chapters on the history of translation examined in that section.

2 Despite the numerous traditions included, as pointed out by Sabio Pinilla (2002), the Portuguese tradition is absent from both editions of this encyclopedia.
In the entry "History of Translation", according to Carr (1961, p. 23), history is defined as "the enquiry conducted by the historian and the series of actual events in the past which are the subject of his/her enquiry" (Woodsworth, 1998, p. 100). Furthermore, the author distinguishes between history, "understood as the events of the past recounted in a narrative form", and historiography, "the discourse upon historical data, organized and analyzed along certain principles"; the latter term is also used to replace historiology, referring to "the methodology of writing history" (Woodsworth, 1998, p. 101). The object of study of the history of translation is established in terms of a broad and rather vague distinction between the history of practice, of theory, or both.

As far as methodological aspects are concerned, Woodsworth claims that little has been done to define a working methodology for the history of translation, and she discusses the two opposing trends in modern historiography (Stanford, 1987, p. 41): (1) "splitting up the field into smaller and smaller plots as specialization increases" and (2) "the rejoining of the pieces in order to tackle a total or global history" (Woodsworth, 1998, p. 104). A conciliation of both trends by means of team work as well as the use of the term "histories" (instead of the singular form "history") to reflect the inherent pluralism of the history of translation are advocated (Woodsworth, 1998, p. 104).

The rest of the entry is devoted to discussing key topics, such as space and time, types of translation, the role of anthologies of statements about translation and the contribution made by the FIT Committee for the History of Translation. All in all, this entry can be considered a valuable first attempt at providing a comprehensive overview of the state of affairs in the area of research of translation history. However, it raises more questions than it answers and remains quite vague in terms of defining the history of translation from an epistemic perspective (i.e. identifying the object of study, objectives or aims, describing suitable models and methods, etc.). 


\section{Questions d'historiographie de la traduction (D'bulst, 2004)}

D'hulst's (2004) contribution in ÜbersetzungTranslation-Traduction. Ein internationales Handbuch zur Übersetzungsforschung / An International Encyclopedia of Translation Studies / Encyclopédie internationale de la recherche sur la traduction (Kittel et al., 2004) focuses on methodological issues. First of all, a clear-cut distinction is established between "histoire", defined as "the totality of scientific activities aiming for the discovery, inventory and analysis of historical facts", and "historiography" as the "historical analysis of the writing of history" (D'hulst, 2004, p. 1063). Furthermore, the author considers it necessary to distinguish between "historiographie de l'objet" (i.e. the historiography of translation) and historiographie de la discipline" (i.e. historiography of translation studies; D'hulst, 2004, pp. 10641065), and he discusses the limitations and methodological constraints of this distinction (D’hulst, 2004, p. 1065).

As far as the historiography of translation is concerned, D'hulst (2004, p. 1065) refers to chronological compilations, works focused on forgotten or lesser studied translational aspects and methodological approaches within the framework of descriptive translation studies. Even though, as he acknowledges, little confluence can be found (2004, p. 1066) within academic research on translation history, two main approaches can be distinguished: (a) the study of segments of information from the past and their configuration; and (b) the study of the processes linked to the context in which translation takes place (ideology, intellectual atmosphere, socio-economic conditions, etc.). D'hulst (2004, pp. 1066-1069) identifies four main problems regarding these two methodological approaches: "the creation of the corpus to be investigated", "the boundaries of the discipline", "the wide range of aspects involved in the 'production' of translations" and "the historical analysis of translated texts".
Two main models in the historiography of Translation Studies can be distinguished. The first one is based on a progressive and cumulative conception of science and tends to discredit earlier theories; the second one considers theories from a hierarchical point of view, distinguishing between central and peripheral theories (e.g. the notion of "equivalence" occupied a central position during from 1960s to 1980 s but is later replaced by other procedures of intercultural transfer; Hymes, 1974 , p. 21), giving rise to a series of binary distinctions that change over time, such as the notion of "equivalence" and source-oriented vs. targetoriented studies (Ordóñez-López, 2015; D’hulst, 2004, pp. 1069-1070).

This entry is written from a reflexive and critical perspective; D'hulst (2004) advocates a comprehensive view of translation, including the contexts of both production and reception with regards to the historiography of translation, and he criticizes the sense of superiority of the present towards the past when dealing with the historiography of translation studies. This entry is somewhat atypical of encyclopedia entries because despite being thorough and well argued, the methodological models described are rather complex and perhaps difficult to apply in actual historical investigation.

\section{History and Translation (Long, 2007)}

"History and Translation" in A Companion to Translation Studies (Kuhiwczak \& Littau, 2007) presents a different structure from that followed in most of the reference works analyzed. Long (2007, p. 63) advocates a comprehensive concept of the history of translation, combining both the theory and the practice of translation, and emphasizes the interconnection between translation and literary history. Furthermore, a strong focus on the purpose of studying the history of translation can be observed, highlighting the contributions and potential benefits of historical research on translation and proposing different ways and methodologies to undertake it (Long, 2007, pp. 64-66). 
Long (2007, pp. 66-76) discusses the difficulty of "navigating" translation history, mainly due to its interdisciplinary nature. She claims that "interdisciplinary research is essential since most sources are interrelated and may be approached from several directions, but gradually a picture of the target area should emerge" (Long, 2007, p. 66). Acknowledging the contribution made byworks such as thoseby Kelly (1979), Bassnett (1980/2002), Munday (2001) and especially Delisle \& Woodsworth (1995) in providing general overviews, Long identifies some key issues around which research on the history of translation can be constructed: language issues, literary issues, religious and philosophical issues, scientific interchange, and exploration and conquest (Long, 2007, pp. 66-75).

Her entry concludes with a general review of this area of research, which is "still in the early stages and somewhat patchy” (Long, 2007, p. 75), and a call for interdisciplinary work with other disciplines within the humanities (Long, 2007, p. 76).

\section{History (St André, 2009)}

In the second edition of the Routledge Encyclopedia of Translation Studies (Baker \& Saldanha, 2009), Part II is also devoted to "History and Traditions" and covers the same translation traditions as the first edition as well as a new entry: Southeast Asian tradition. In the "History" entry (St André, 2009, pp. 133-136), "history" is defined in terms of its scope, with a distinction established between "History of translation theory and criticism" and "History of translation practice" in an attempt to cover all the different issues and objects of historical research in translation studies.

In this work, St André discusses the shifts in methodology and approach triggered by the so-called "cultural turn" (2009, p. 133) which have led to history being seen as narrative in nature, subjective and concerned with ordinary people and popular culture (St André, 2009, p. 133), as opposed to a factual, "objective" Eurocentric history, concerned with great men and ideas. The author comments on Pym's (1998) methodological proposal, which is characterized by his call for attention to people (to the translators, rather than to the texts) and discusses the incorporation of new aspects into the historical study of translation, which implies a broadening of the scope of the object of study. However, St André concludes that the lack of consensus, as well as the imprecision of the concept of "translation" and "translator" mean that in practice "each historian draws their own boundaries" (St André, 2009, p. 134).

In comparison with the first edition of the Routledge Encyclopedia of Translation Studies, a more critical approach can be found in this work. On the one hand, St André criticizes the Eurocentric approach which has dominated historical research on translation (2009, p. 133); on the other hand, the author calls for a more self-critical perspective, especially regarding the wide-spread argument that the history of translation should contribute to increasing the visibility and recognition of translators, given that, in his opinion, this appeal might lead to lobbying and uncritical revisionist research.

\section{Translation History (D'bulst, 2010)}

D'hulst's contribution in the Handbook of Translation Studies vol.1 (Gambier \& van Doorslaer, 2010) focuses on methodology and contains a detailed proposal of a comprehensive methodology for historical research. First, in an attempt to clearly define the object of study of translation history, D’hulst (2010, pp. 397-399) presents a distinction in which three levels of analysis are identified: history, "the proper sequence of acts, events, ideas, discourses, etc." (D’hulst, 2010, p. 397); historiography, "the history of the practices of history-writing” (D’hulst, 2010, p. 397); and metahistoriography, "the explicit reflection on the concepts and methods to write history and also on epistemological and methodological problems that are related to the use of these concepts and methods" (D'hulst, 2010, p. 398). D'hulst adopts a critical position towards Holmes' map of 
translation studies, arguing that it does not consider the fact that historical research can involve the "entire set of scholarly activities dealing with translation" (2010, pp. 398-399), including process and function-oriented activities and translation theories, criticism and training.

The author presents a comprehensive methodological model which covers a wide variety of aspects related to translation, each of them potential objects of study in historical research in their own right: quis? quid? ubi? quibus auxiliis? cur? quomodo? quando? (D’hulst, 2010, p. 399). He briefly discusses these research questions, linking them with various methodological and conceptual frameworks both within translation studies and other disciplines, such as history (e.g. D'hulst's suggestion to apply Braudel's (1949) distinction of three time levels - long term, conjuncture and short term).

Methodology is also the focus of D'hulst's conclusion; the author discusses the historian's rationale, warning of the risks of examining the past with the aim of somehow making it fit in with presentday frameworks and models and of establishing oppositions between the latter and the present, projecting a linear vision in terms of originality and progress (D'hulst, 2010, pp. 403-404).

\section{Translation History (Tahir-Gürçağlar, 2013)}

The "Translation History” entry (Tahir-Gürçağlar, 2013, pp. 131-143) in The Routledge Handbook of Translation Studies (Millán \& Bartrina, 2013) starts by locating the history of translation within translation studies, viewing it as a sub-area of this discipline, and commenting on its fragmentary nature, attributable to the wide variety of methods and approaches, the scarcity of sources and translation's own diffuse nature (Tahir-Gürçağlar, 2013, p. 131). This chapter focuses on the ways historical findings have been gathered and interpreted in the writing of narratives about translation (TahirGürçağlar, 2013, p. 132), thus granting a central position to methodological issues.
Tahir-Gürçağlar (2013, pp. 131-133) discusses the conceptual and practical differences between "translation history" and "translation historiography" reviewing the definitions provided by D'hulst $(2001,2007,2010)$ and Woodsworth (1998). From the point of view of methodology, the author pays special attention to the shift experienced within translation history towards a narrative perspective, discussing the works of D'hulst (2007), Venuti (2005) and Pym (2000).

The relevance of translation history is also discussed in this entry. Tahir-Gürçağlar (2013, pp. 133-134) examines previous work in which the role of historical research on translation has been explored (D'hulst, 1994, 2001; Pym, 1998, 2000; Bastin, 2005; Venuti, 2005) and underlines both the predominance of an applied perspective and the wide variety of reasons that can motivate the study of the history of translation. This, in turn, implies the co-existence of a wide range of working methodologies. The author therefore suggests using the term "histories of translation" to better account for the wide variety of studies carried out from a historical perspective (TahirGürçağlar, 2013, p. 135).

Concerning the key areas of study in translation history, Tahir-Gürçağlar (2013, pp. 135-137) points out that literary translation and the translation of sacred texts are the two areas which have been most frequently studied. The author applies the classification proposed by Woodsworth (1998): histories that are limited in space and time, histories focusing on types of translation, and histories dealing with great moments in the history of translation (Tahir-Gürçağlar, 2013, p. 136), adding a further category, histories focusing on translators or "translator history" (Milton et al., 2001), to briefly review and classify the most significant contributions.

After examining some of the most representative methodological proposals (Pym, 1998; D’hulst, 2001; Bastin, 2006), Tahir-Gürçă̆lar (2013, pp. 137-140) discusses the contribution of 
descriptive translation studies and of the "sociological turn" to historical research and identifies some methodological challenges that translation history should confront: (a) periodization, (b) the overemphasis of institutional translation history and (c) the delimitation of history, i.e. "when is history?” (Tahir-Gürçağlar, 2013, p. 139).

The entry concludes with the identification of potential future areas of study, such as self-translations, oral translation or interpretation, based on Santoyo (2006), and with references to works incorporating new methodologies borrowed from history, such as "histoire croisée" (Wolf, 2009), oral history (Torikai, 2009; Ben-Ari, 2009) and microhistory (Adamo, 2006).

\section{Descriptive Historical Entries}

The entries and chapters included in this category provide a descriptive review of the most significant contributions, authors and events in the history of translation.

\section{Geschichte des Übersetzens (Woodsworth, 1999)}

In the Handbuch Translation (Snell-Hornby, et al., 1999), the history of translation and the history of interpreting are approached separately. The chapter dedicated to the history of translation starts by discussing the relevance of translation studies (Woodsworth, 1999, pp. 39-42), which is described as a young discipline, despite the fact that translation, as an activity, is as old as language itself. According to Woodsworth, with reference to Berman (1984), the history of translation is an essential component of modern translation studies.

Woodsworth (1999, pp. 39-42) focuses on four periods in the history of translation: Antiquity, the Middle Ages, the Renaissance and Reformation, and the Romantic period to the present day. The author reviews some of the most significant translators and schools from each period: Cicero and Jerome; the Baghdad School and the School of Translators of Toledo; Luther and Tyndale; and Goethe, Schleiermacher, Novalis and Humboldt respectively. The links between their biographical circumstances and their activity as translators are emphasized, as well as how their translations have influenced society. Finally, Woodsworth (1999, p. 42) comments on the growth of international relations in the twentieth century and its consequences for the development of translation studies.

\section{Historical Overview of Translation (Sofer, 1999)}

The second chapter of The Translator's Handbook covers the history of translation (Sofer, pp. 19-32); attention is paid to the way translation has contributed to the development of cultures and civilizations. In the discussion of the role played by translation through some of the most influential historical events and the figure of the translator and the output of translators such as Jerome, Luther and Yehudah ibn Tibbon are also highlighted (Sofer, 1999, pp. 22-28).

Sofer (1999, pp. 19-31) succinctly discusses the relevance of translation for the history of the JudeoChristian-Islamic world, especially during three periods in which, according to the author, there was a "high level of activity in the field of translation": "the beginning of the Christian era", from "the birth of Islam in the seventh century" to the establishment of the so-called School of Translators of Toledo; and "the third key period", today (Sofer, 1999, p. 19). The author underlines the importance of the translation of sacred texts, especially the Bible, in the development of civilizations and cultures, and he comments on the key role played by translation in the conquest of the New World (1999, p. 21). The chapter ends with a review of the position occupied by translation in socio-political events, such as rule by totalitarian regimes and the re-emergence of national languages throughout the world (Sofer, 29-30).

\section{The Diachronic Study of Translation (Das, 2005)}

The volume $A$ Handbook of Translation Studies (Das, 2005) includes a chapter on the history of translation (Das, 2005, pp. 9-26) with a review of the most significant contributions from the 
Roman times to the second half of the $20^{\text {th }}$ century. The author discusses the changes that the concept of translation has undergone throughout the centuries, briefly presents the key topics present in the debate on translation (i.e. the opposition between word-for-word and sense-for-sense translation) and comments on the functions that translation has had (i.e. dissemination of the word of God and cultural enrichment) throughout history (Das, 9-10).

Regarding the periodization of the history of translation, Das (2005, pp. 11-12) reviews the proposals made by Steiner (1975) and Bassnett-McGuire (1991) and, following the latter, claims that a careful, individual study of each author and the relation of his or her work with the historical context in which it emerged is necessary. Therefore, Das (2005, pp. 12-22) summarizes, in chronological order, some of the most influential contributions such as those by Cicero and Horace, Quintilian, Folena, Dolet, Dryden, Goethe, Tytler, Schleiermacher, and Arnold. Finally, attention is drawn to the translation scene in India (Das, 2005, pp. 23-25), with special emphasis on the role played by translation during the colonization period and the British Empire.

This work differs from other similar studies, as a non-Western tradition is included; furthermore, and rather uncommonly for reference works, a wide range of authors are covered, and special attention is paid to the discussion of their individual contributions.

\section{The History of Translation Practice and Early "Theory" (Munday, 2009)}

The first chapter of The Routledge Companion to Translation Studies (Munday, 2009), "Issues in Translation Studies", includes a section dedicated to the history of translation in which the origins of writing on translation, more specifically on the practice of translation, are reviewed. According to Munday (2009, p. 1), writing on translation in the West is traditionally held to begin with Cicero and his distinction between word-for-word and sensefor-sense translation, describing his strategy while translating Greek classics. Even more important (in terms of affecting the concept of translation) is the translation of the Bible, which involves (re)writing the word of God and has contributed considerably to the endurance of the discussion about accuracy and faithfulness. Munday (2009, p. 3) comments on Jerome's Letter to Pammachius, where he explains his general strategy for translating, sense for sense instead of word for word, but clearly states that the translation of the Holy Scripture calls for a different approach; Munday also discusses Luther's defense, in Sendbrief vom Dolmetschen, of his translation of the Bible into modern German.

Munday (2009, p. 3) acknowledges the impossibility of providing a summary of historical writings in this section and provides the reader with a wide range of references to get a more in-depth vision of the different historical periods and traditions. He concludes with some interesting remarks on the historical discourse of translation, namely the dominant role of men and of European writing and languages as well as the focus on the practice of translation itself, at least until the $15^{\text {th }}$ and $16^{\text {th }}$ centuries, when the first attempts at theoretical conceptualization can be found (Munday, 2009, pp. 3-4).

\section{The History of Translation in The Oxford Handbook of Translation Studies}

The first section of The Oxford Handbook of Translation Studies (Malmkjaer \& Windle, 2011) is dedicated to the history of translation and consists of three different chapters entitled "European Thinking on Secular Translation" (Windle \& Pym, 2011), "Secular Translation: Asian Perspectives" (Wakabayashi, 2011) and "Translating the Sacred" (Barnes, 2011). This structure already implies a more in-depth approach to the area of study, acknowledging the existence of different approaches to translation, depending on the nature of texts and on the overall cultural tradition (Western or Eastern).

Windle \& Pym (2011, pp. 7-22) provide a survey of the history of translation theory in Europe, paying special attention to the 20th century, especially to more recent work. While in its early times 
in particular, translation was highly influenced by religion, the focus here is on secular translation. The authors discuss some of the more influential contributions which have shaped the evolution of thinking on translation throughout history. It is especially noteworthy that instead of using some of the more established periodizations, the history of translation is reviewed following a periodization in which chronological and cultural criteria are combined with conceptual issues and influential authors of the time. The resulting periods are "Early history: faith and faithfulness", "Biblical influences", "Bienséance: The seventeenth and eighteenth centuries", "Alexander Fraser Tytler", "Romanticism; the nineteenth century", "The early twentieth century: reiterations, revolutions, and reactions" and "Late twentieth century" (Windle \& Pym, 2011, pp. 8-15).

Wakabayashi (2011, pp. 23-36) gives an overview of the history of thinking on secular translation in Asia, particularly in China and Japan, analyzing how the conception of translation has evolved. The author also examines present-day approaches with a focus on the shifts experienced in terms of methodology and on the role played by translation in the shaping of the respective literary traditions. Finally, Wakabayashi (2011, p. 36) discusses aspects of the future development of translation thinking (e.g. "reciprocal and constructive" dialogue between Western insight and Asian traditions), underlining the growing global importance of Asian traditions.

Barnes (2011, pp. 37-54) deals with the translation of sacred texts throughout history, covering the translation of the Bible, the Qur'an and the translation of Buddhist texts. The author reviews some of the most influential translations of the Bible and, more briefly, explores the contexts and situations surrounding the translations of the Qur'an and Indian Buddhist texts. Uncommon for reference works entries, Barnes (2011, pp. 49-54) includes some examples of translations of the Bible and the Qur'an, comparing different versions.

\section{A Critical Account of the "History of Translation" in Reference Works}

This section offers a critical review of the entries and chapters on the history of translation presented above.

\section{The History of Translation \\ from an Epistemic Perspective}

In order to evaluate how the history of translation has been presented in epistemology-oriented reference works, some epistemic considerations should be made. Furthermore, it is necessary to consider how translation studies has been constructed as a discipline (or an interdiscipline). It is important to bear in mind that translation studies is a relatively new discipline that still lacks standardization in terms of metalanguage and the establishment of a widely accepted conceptual map of the field. Consequently, it is only logical to expect, to a certain extent, a similar scenario for the area of knowledge of the history of translation.

Krishnan (2009) identifies six characteristics that an area of knowledge must fulfill to be considered a discipline:

1. Disciplines have a particular object of research (e.g. law, society, politics), though the object of research may be shared with another discipline;

2. Disciplines have a body of accumulated specialist knowledge referring to their object of research, which is specific to them and not generally shared with another discipline;

3. Disciplines have theories and concepts that can organize the accumulated specialist knowledge effectively;

4. Disciplines use specific terminologies or a specific technical language adjusted to their research object;

5. Disciplines have developed specific research methods according to their specific research requirements; and maybe most crucially

6. Disciplines must have some institutional manifestation in the form of subjects taught at universities or colleges, respective academic departments and professional associations connected to it. (Krishnan, 2009, p. 9)

Mayoral-Asensio (2001) provides an extensive analysis of the status of Translation Studies and 
lists a series of pending tasks scholars should tackle in order to contribute to the consolidation of the discipline; these can also be applicable to the definition and delimitation of the history of translation as an area of research:

- to define the object or objects of study clearly

- to contribute to the standardization of the basic concepts and terminology

- to construct more rigorous explanatory models

- to establish which fields of translation studies permit different types of observation and description, e.g. experimental, inferential statistics, or black box

- to include, in published research, the information that is required for verification, replication, etc.[... ${ }^{3}$ (Mayoral-Asensio, 2001, p. 165)

There are notable coincidences in the quotes above, enabling us to identify some key issues that, from an epistemic perspective, any discipline and area of knowledge (to a lesser extent, perhaps) should pay attention to. These issues, as shown in the "Epistemology-oriented Entries" section, are also fundamental in defining the area of knowledge of translation history and are, more or less explicitly, present in the entries examined.

First of all, the status scholars confer to translation history is noteworthy: "sub-discipline" (Woodsworth, 1998), "branche [de la traductologie]” (D’hulst, 2004), "area of study” (Long, 2007), "field of research" and "subfield [of Translation Studies]” (Tahir-Gurçağlar, 2013). Without going into further detail, given that in most cases no justification is provided for the use of the different terms, it stands to reason that the choice of term influences, or is influenced by, the respective authors" conception of the history of translation itself. Furthermore, it is interesting to note the names given to this area of knowledge and evaluate to what extent terminology is standardized. A wide consensus can be

3 Our translation. observed in the term used to name the area of knowledge, "history of translation" or "translation history"; however, lack of standardization and some conceptual overlap are found when dealing with the distinctions made by scholars to refer to the different approaches and focuses within historical enquiry: historiography, historiology, metahistoriography, history of translation practice, history of translation theory, history of translation theory and criticism. An example of this overlap is Tahir-Gürçağlar's usage of the term "history": "I use the term translation history, it should be understood in the sense of historiography [...]” (Tahir-Gürçağlar, 2013, p. 132).

These distinctions are, at least partly, due to

the fact that historical viewpoints may be applied to the entire set of scholarly activities dealing with translation, [...] including process and function oriented activities, as well as translation theories and even applied forms of research such as criticism or training.

(D’hulst, 2010, pp. 398-399)

The previous distinctions depend, among other things, on the object(s) of study considered to be central in the history of translation. As shown in the "Epistemology-oriented Entries" section, the most common distinction is that in which "history" is distinguished from "historiography". Similarly, scholars seem to agree, at least in broad terms, on the distinction between the "history of translation" ("translation" here is understood as the act of translating, the practice) and the "history of translation theory" (i.e., the historical study of reflection on translation).

On the basis of this central distinction, each scholar underlines different aspects: e.g. D’hulst (2010) emphasizes the importance of the circumstances and contexts in which translations are produced, Long (2007) focuses on the relation between translation and literature, and St André (2009) discusses the difficulty of identifying the object(s) of study in a clear-cut manner due to the diffuse nature of translation itself and how its conception has evolved throughout time. This, as well as the complexity 
of applying temporal and spatial delimitations (and thus, cultural and linguistic) as pointed out, for instance, by Woodsworth (1998) and St André (2009), has led to the claim of the use of the term "histories" (Woodsworth, 1998, p. 104; Long, 2007, p. 63; Tahir-Gürçağlar, 2013, p. 135), to better account for the wide variety of potential objects of study (and approaches and methodologies) of historical research. It should also be noted that the interdisciplinarity involved in the study of translation history makes it more complex to anchor this area of research and to provide it with a solid epistemic scaffolding. In spite of the interdisciplinary nature of translation studies being widely acknowledged and embraced within scholarship, academics are still, more or less consciously, following and applying the traditional, long-established and, relatively, clear-cut disciplinary boundaries.

Methodology is a key issue in most of the entries examined, as many authors consider it necessary to provide the history of translation with appropriate research methods; however, as pointed out in some entries (e.g. St André, 2009), few attempts have been made to propose specific methods. Attention has been paid to the methodological problems arising within historical inquiry (D'hulst, 2004), and a series of key areas of research are suggested (e.g. TahirGürçağlar, 2013). D’hulst (2010) puts forward one of the most detailed working methodologies, based on a wide range of objects of study, such as who paid for the translations, or why texts were chosen to be translated, and he underlines the need to interpret data and facts in awareness of their historical context; Tahir-Gürçağlar (2013) reviews some of the most influential proposals, such as those by Pym (1998), Venuti (2005) and D'hulst (2010). It is also worth mentioning that the interdisciplinary nature of the history of translation becomes especially apparent when dealing with methodology; references to methodological models of History are frequently made, e.g. Woodsworth (1998), St. André (2009) and Tahir-Gürçağlar (2013). Nevertheless, no specific methodological proposals from historians are described in detail.
As far as the two remaining characteristics of the list presented by Krishnan (2009, p. 9) are concerned (i.e. having a body of accumulated specialist knowledge and some institutional manifestation in the form of modules taught at universities, academic departments, etc.), as highlighted in some of the entries analyzed, a growing number of studies are dedicated to the history of translation (St André, 2009, p. 133; Tahir-Gürçağlar, 2013, p. 131). In fact, in the chapter by Tahir-Gürçağlar (2013), the most recent one examined here, a notable increase in the number of references dealing with the history of translation (mainly devoted to methodological issues) can be observed. However, as also suggested by some authors (Long, 2007, p. 75; Tahir-Gürçağlar, 2013, p. 131), historical investigation has until now been patchy and fragmented. On the other hand, no explicit reference to the institutional manifestation (cf. Krishnan, 2009 , p. 9) of translation history can be found.

\section{The Discourse on the History of Translation}

The entries dedicated to the discourse of translation history share the intention of offering the reader a brief account of the most representative historical events (schools, etc.), authors or periods, which have left a mark on the way translation (and translators) have been considered in the past. Some similarities between the entries can be found, but despite these being relatively short pieces of work, it is also possible to distinguish different approaches when dealing with translation from a historical perspective.

One of the common features of all the entries and chapters analyzed is the distinction between different periods in the historical review of the discourse on translation (more specifically, on translation practice); it is, nevertheless, interesting to note that little coincidence can be found in the periods themselves. The issue of periodization is, as Foz notes, "an indispensable division for defining and delimiting historical evolution, as well as the historical object itself" (2006, p. 136), and has been discussed in numerous works (cf. Sabio-Pinilla 
\& Ordóñez-López, 2012, pp. 45-49; Das, 2005, pp. 11-12) where the suitability of the use of literary or simply cultural and more traditional periodizations for the study of the history of translation is discussed. In practice, however, as shown in the entries examined, in spite of the relatively wide-spread acceptance of some proposals (e.g. Steiner, 1975; Ballard, 1992), scholars tend to use customized periodizations, according to their conception of translation itself and the dimensions or aspects they wish to underline.

The summarized reviews of the history of translation provided (see the "Descriptive historical entries" section) reveal that some periods have received considerably more attention than others (e.g. Antiquity and the Middle Ages vs. the $18^{\text {th }}$ century), perhaps, as explained by Sofer (1999), due to the fact that more translation activity took place in them. This implies that some authors are commonly quoted, while others are left out of the (canonical) discourse of translation history. The same observation can be made regarding the traditions that are commonly included in the (canonical) review of the history of translation; see Ordóñez-López (2016) for an in-depth study of the shaping of the canon of the historical discourse on translation. In most cases, studies are limited to the Western (if not European) tradition, with the exception of, at least partly, Das (2005), Wakabayashi (2011) and, to a certain extent Windle \& Pym (2011) and Barnes (2011).

It is only fair to admit that the (canonical) historical discourse on translation is notably Westernized, which may be due to the fact that entries in reference works aim to offer a general, usually mainstream, overview of the object of study (one can also think of other influencing factors such as the origin/affiliation of researchers, the accessibility of sources, or the complexity of approaching otherness, for instance). Furthermore, it can be observed how the historical discourse on translation is built upon literary translation; other types of translation, e.g. legal or scientific translation, usually fall beyond the attention of scholars.
Apart from the chronological review of the most representative periods, events and authors, each of the entries examined distinguishes itself from the others by emphasizing different aspects: for instance, Sofer (1999) pays particular attention to the figure of the translator, while Munday (2009) underlines the importance of the translation of sacred texts (especially the Bible) and how this has influenced historical discourse on translation. The three contributions included in Malmkjaer \& Windle's (2011) handbook are original in their focus, as they choose a narrower scope, rather than approaching the history of translation as a whole. Wakabayashi (2011) focuses on individual traditions, Barnes (2011) on events, while Windle \& Pym's (2011) chapter, despite its more general approach, is characterized by its attention to $20^{\text {th }}$-century contributions, which receive very little (if any) attention in the other entries analyzed.

\section{Concluding Remarks}

The examination of the entries and chapters dealing with the history of translation in this paper reveals the co-existence of two main trends. On the one hand, some entries are aimed at defining the history of translation as an area of knowledge and establishing the foundations of this area of research. On the other hand, others consist of brief accounts of the most significant periods, authors and events that have influenced the discourse on, or the practice of, translation throughout history.

Bearing in mind that the contributions examined are included in reference works, it is inevitable that some similarities and, to a certain extent, some repetition in both the structure and the contents themselves will be found in both epistemologyoriented and descriptive historical contributions. Also, as is typical of reference works, the entries and chapters are brief and at times superficial as space limitations call for a general, succinct account of the topic.

The epistemology-oriented entries show that, despite scholars being aware of the need to 
define and delimit the object(s) of study, the diffuse and humanistic nature of translation and the co-existence of multiple objects of study within the discipline of translation studies (cf. MayoralAsensio, 2001, p. 132), which call for diverse methods and approaches, make it practically impossible to determine clearly what the object or objects of study should be. As a result of this, in practice, a wide variety of historical studies, focused on an equally wide range of aspects, can be found. Consequently, it is also difficult to find methodological proposals that are "universally" applicable and appropriate within the area of knowledge.

Although, given the function of reference works, it is understandable that entries are intended to provide a clearly delimited overview of the area so that the readership can easily grasp an idea of the state of affairs. It should be taken into consideration that translation, like any other field within the humanities, is not easily defined or delimited; absolute truths, simplistic interpretations and strict delimitations are always difficult to apply within this field of knowledge.

In spite of the recurrent use of the terms interdisciplinary and interdisciplinarity (especially in the epistemology-oriented contributions), few real cases are found in which an interdisciplinary approach is adopted, apart from brief and, to a certain extent, anecdotic references to methodological and perspective shifts and the use of some definitions from historians. Even though, as pointed out by D'hulst (2010, p. 404), the history of translation should, if possible, find a way to develop within translation studies, there is absolutely no reason not to turn to history as far as methodology is concerned. In practice, the inherent interdisciplinary nature of the history of translation should be used in a positive way, taking advantage of the insights, approaches and methods of history to study the past of translation, creating successful synergies, and working through the necessary adaptations and customizations. It would make no sense to aim at a new start, as though attempting to reinvent the wheel.
One cannot but notice the emphasis that is placed on the rationale of historical research on translation. On the one hand, this can make the readership aware of the contribution of studying the past both to the discipline and to the profession; on the other hand, it raises questions about the need to justify the attention paid to this area of knowledge, which is not the case in other areas of translation, such as audiovisual translation, for instance. This emphasis on the rationale may be due to the fact that the history of translation is sometimes considered a "poor relation", as mentioned in the introduction.

To sum up, the examination of the entries and chapters on the history of translation carried out in this paper allows us to conclude that, from an epistemic perspective, this is a multifaceted area of knowledge that covers a wide variety of viewpoints; as a result, despite the recurrent effort to provide clear-cut delimitations in terms of object(s) of study and suitable methodology, etc., the history of translation continues to be a very diversified and thus, rather diffuse area of knowledge. However, in recent decades, a progression in terms of methodological proposals, providing definitions and widening its scope to include nonWestern traditions can be observed.

As for the historical account provided in reference works, the entries examined tend to present a canonical overview (with regards to the periods, authors, events and traditions covered), contributing to the dissemination of a Westernized ${ }^{4}$, and perhaps also simplistic, account of the history of translation, although a more inclusive approach is adopted in the case of Malmkjær \& Windle (2011). Future research will explore whether this widening in scope is consolidated in more recently published reference works. With all the pitfalls discussed in this paper and the acknowledgment that there are still some challenges to be faced and a (perhaps not so long) way to go, as pointed out in many of

4 Efforts to overcome this limited vision have been made outside the domain of reference works too, for instance in anthologies of translation discourse, e.g. Cheung (2006). 
the entries examined, the fact that the history of translation is included in most reference works on translation shows that it is considered a fundamental component of translation studies and reveals scholarly interest in studying the past.

\section{References}

Adamo, S. (2006). Microhistory of translation. In Georges Bastin \& Paul Bandia (Eds.), Charting the future of translation history (pp. 80-99). Ottawa University Press.

Ballard, M. (1992). De Cicéron à Benjamin. Traducteurs, traductions, réflexions. Presses Universitaires de Lille.

Baker, M., \& Malmkjær, K. (Eds.) (1998). Routledge encyclopedia of translation studies. Routledge.

Baker, M., \& Saldanha, G. (Eds.) (2008). Routledge encyclopedia of translation studies. Routledge.

Barnes, R. (2011). Translating the sacred. In K. Malmkjaer \& K. Windle (Eds.), The Oxford handbook of translation studies (pp. 37-54). Oxford University Press.

Bassnett, S. (1980[2002]). Translation studies. Methuen.

Bassnett McGuire, S. (1991). Translation studies: Revised edition. Routledge.

Bastin, G. (2005). Introduction. Meta, 50(3), 797-799. https://doi.org/10.7202/011596ar

Bastin, G. (2006), Subjectivity and rigour in translation history: The Latin American case. In G. Bastin, \& P. Bandia (Eds.), Charting the future of translation history (pp. 111-130). Ottawa University Press.

Bastin, G., \& Bandia, P. (Eds.) (2006). Charting the future of translation history. Ottawa University Press.

Ben-Ari, N. (2009), Popular literature in Hebrew as a Marker of Anti-Sabra Culture, Translation Studies, 2(2), 178-195.

Berman, A. (1984). L'épreuve de l'étranger. Gallimard.

Braudel, F. (1949). La Méditerranée et le monde méditerranéen à l'époque de Philippe II. A. Colin.

Cheung, M. (Ed.) (2006). An anthology of Chinese discourse on translation. Volume 1: From earliest times to the Buddhist project. St. Jerome.

Das, B. K. (2005). A handbook of translation studies. Atlantic.

Delisle, J. \& Woodsworth, J. (Eds.) (1995). Translators through history. John Benjamins.

D'hulst, L. (2001). Why and how to write translation histories? In J. Milton (Ed.), Emerging views on translation history in Brazil (pp. 21-32). Crop.
D'hulst, L. (2001). Why and how to write translation histories? In J. Milton (Ed.), Emerging views on translation history in Brazil (pp. 21-32). Crop.

D'hulst, L. (2004). Questions d'historiographie de la traduction [Issues in the historiography of translation]. In H. Kittel, J. House, \& B. Schultze (Eds.), Übersetzung-Translation-Traduction. Ein internationales Handbuch zur Übersetzungsforschung/An International Encyclopedia of Translation Studies/ Encyclopédie internationale de la recherche sur la traduction (pp. 1063-1073). Walter de Gruyter.

D’hulst, L. (2010). Translation history. In Y. Gambier, \& L. van Doorslaer (Eds.), Handbook of Translation Studies (vol. 1, pp. 397-405). John Benjamins.

Foz, C. (2006). Translation, history and the translation scholar. In G. Bastin, \& P. Bandia (Eds.), Charting the future of translation history (pp. 131-143). Ottawa University Press.

Gambier, Y., \& Doorslaer, L. v. (Eds.), Translation studies bibliography. John Benjamins. https://doi.org/10.1075/etsb

Hymes, D. H. (1974). Studies in the history of linguistics: traditions and paradigms. Bloomington.

Hoof, H. v. (1993). Dictionnaire universel des traducteurs. Slatkine.

Kelly, L. G. (1979). The true interpreter: A bistory of translation theory and practice in the West. Basil Blackwell.

Krishnan, A. (2009). What are academic disciplines? Some observations on the disciplinarity vs. interdisciplinarity debate. University of Southampton, National Centre for Research Methods.

Kuhiwczak, P., \& Littau, K. (2007). A companion to translation studies. Multilingual Matters.

Lafarga Maduel, F., \& Pegenaute Rodríguez, L. (2009). Diccionario histórico de la traducción en España. Gredos.

Lépinette, B. (1997). La historia de la traducción. Metodología. Apuntes bibliográficos (Vol. 14). Lynx.

Long, L. (2007), History and translation. In P. Kuhiwczak, \& K. Littau (Eds.), A Companion to translation studies (pp. 63-76). Multilingual Matters.

Malmkjaer, K., \& Windle, K.(Eds).(2011). The Oxfordhandbook of translation studies. Oxford University Press. 10.1093/oxfordhb/9780199239306.001.0001

Mayoral-Asensio, R. (2001), Aspectos epistemológicos de la traducción. Universitat Jaume I.

Millán, C., \& Bartrina, F. (2013), The Routledge handbook of translation studies. Routledge.

Milton, J., Pagano, A., \& Hirsch, I. (2001). Interview with Anthony Pym. In J. Milton (Ed.), Emerging views on translation history in Brazil (pp. 273-184).Crop. 
Munday, J. (2001). Introducing translation studies. Routledge.

Munday, J. (Ed.). (2009). The Routledge companion to translation studies. Routledge.

Ordóñez-López, P. (2016) Shaping the canon of translation history: Translation anthologies in the Iberian Peninsula. The Translator, 22(3), 340-353. 10.1080/13556509.2016.1149753

Oxford University Press. (2020). Lexico.com. https://www. lexico.com/definition/wake [Accessed 4/8/2020]

Pym, A. (1998). Method in translation history. St Jerome Publishing.

Pym, A. (2000). Negotiating the frontier: Translators and intercultures in Hispanic history. St. Jerome.

Radó, G. (1964). La traduction et son histoire. Babel, 10(1), 15-16. https://doi.org/10.1075/babel.10.1.05rad

Sabio-Pinilla, J. (2002). Inclusiones y exclusiones en la historia de la traducción: el caso de Portugal. Mundo Eslavo: Revista de Cultura y Estudios Eslavos, (1), 155-166.

Sabio-Pinilla, J., \& Ordóñez-López, P. (2012). Las antologias sobre la traducción en el ámbito peninsular. Análisis y estudio, Peter Lang.

Santoyo, J. (2006). Blank spaces in the history of translation. In G. Bastin, \& P. Bandia (Eds.), Charting the future of translation history (pp. 11-43). Ottawa University Press.

Snell-Hornby, M., Hönig, H., Kussmaul, P., \& Schmitt, P. (1999), Handbuch Translation. Stauffenburg.

Sofer, M. (1999). The translator's handbook [ $3^{\text {rd }}$ revised ed.]. Schreiber Publishing.

St André, J. (2009). History. In M. Baker, \& G. Saldanha (Eds.), The Routledge encyclopedia of translation studies [ $2^{\text {nd }}$ Ed.] (pp. 133-136). Routledge.
Steiner, G. (1975), After Babel. Aspects of language and translation. Oxford University Press.

Tahir-Gürçağlar, Ş. (2013). Translation history. In C. Millán, \& F. Bartrina (Eds.), The Routledge handbook of translation studies (pp. 131-143). Routledge.

Takeda, K., \& Baigorri-Jalón, J. (2016). Introduction. In K. Takeda, \& J. Baigorri-Jalón (Eds.), New insights in the history of interpreting (pp. vii-xvi). John Benjamins.

Torikai, K. (2009). Voices of the invisible presence: Diplomatic interpreters in post-World War II Japan. John Benjamins.

Venuti, L. (2005). Translation, history, narrative. Meta, 50(3), 800-816. https://doi.org/10.7202/011597ar

Wakabayashi, J. (2011). Secular translation. Asian perspectives. In K. Malmkjaer, \& K. Windle (Eds.), The Oxford handbook of translation studies (pp. 23-36). Oxford University Press.

Windle, K., \& Pym. K. (2011). European thinking on secular translation. In K. Malmkjaer, \& K. Windle (Eds.), The Oxford handbook of translation studies (pp. 7-22). Oxford University Press.

Wolf, M. (2009). Crossing histories: The metamorphoses of the translation field in the Habsburg monarchy under the perspective of "histoire croisée". Abstract presented to the International Workshop on 'Rethinking Methods in Translation History', 25-26 September, Okan University, Istanbul.

Woodsworth, J. (1998). History of translation. In M. Baker, \& K. Malmkjaer (Eds.), The Routledge encyclopedia of translation studies (pp. 100-105). Routledge.

Woodsworth, J. (1999). Geschichte des Übersetzens. In M. Snell-Hornby, H. Hönig, P. Kussmaul, \& P. Schmitt (Eds.), Handbuch Translation (pp. 3942). Stauffenburg-Verlag.

\section{Appendix}

Searches conducted in the Translation Studies Bibliography database yielded the following results (in chronological order):

1993. Henri van Hoof. Dictionnaire universel des traducteurs. Slatkine.

1998. Mona Baker \& Kirsten Malmkjær (Eds.). Routledge encyclopedia of translation studies. Routledge.

1999. Mary Snell-Hornby, Hans G. Hönig, Paul Kussmaul \& Peter A. Schmitt. Handbuch translation. Stauffenburg.

1999. Morry Sofer.The translator's handbook. Schreiber.

2004. Harald Kittel, Armin Paul Frank, Norbert Greiner, Theo Hermans, Werner Koller, José Lambert \& Fritz Paul (Eds.). Übersetzung, translation, traduction. Ein internationales Handbuch zur Übersetzungsforschung / An International Encyclopedia of Translation Studies / Encyclopédie internationale de la recherche sur la traduction, Vol. 1, Berlin/ New York: Walter de Gruyter. 
2005. Kumar Das. A handbook of translation studies. Atlantic.

2007. Harald Kittel, Armin Paul Frank, Norbert Greiner, Theo Hermans, Werner Koller, José Lambert \& Fritz Paul (Eds.). Übersetzung, translation, traduction. Ein internationales Handbuch zur Übersetzungsforschung / An International Encyclopedia of Translation Studies / Encyclopédie internationale de la recherche sur la traduction, 2. Walter de Gruyter.

2007. Kuhiwczak, Piotr \& Karin Littau. A companion to translation studies. Multilingual Matters.

2008. Baker, Mona \& Gabriela Saldanha (Eds.). Routledge encyclopedia of translation studies. Routledge.

2009. Munday, Jeremy. The Routledge companion to translation studies. Routledge.

2009. Lafarga Maduel, Francisco \& Luis Pegenaute Rodríguez. Diccionario histórico de la traducción en España. Gredos.

2010. Gambier, Yves \& Luc van Doorslaer (Eds.). Handbook of translation studies, 1. John Benjamins.

2011. Gambier, Yves \& Luc van Doorslaer (Eds.). Handbook of translation studies, 2. John Benjamins.

2011. Malmkjær, Kirsten \& Kevin Windle (Eds.). The Oxford handbook of translation studies. Oxford University Press.

2012. Gambier, Yves \& Luc van Doorslaer (Eds.). Handbook of translation studies 3. John Benjamins.

2013. Gambier, Yves \& Luc van Doorslaer (Eds.). Handbook of translation studies 4. John Benjamins.

2013. Millán, Carmen \& Francesca Bartrina. The Routledge handbook of translation studies. Routledge.

How to reference this article: Ordóñez-López, P. (2020). Dealing with the past: Definitions and descriptions of the history of translation. Íkala, Revista de Lenguaje y Cultura, 25(3), 797-814. https:/ doi.org/10.17533/udea.ikala.v25n03a11 